\title{
INVESTIGATION ON THE ROAD MORTALITY OF ANURAN SPECIES ON THE IKORODU-EPE/EJIRIN-IJEBU ODE ROADS IN LAGOS AND OGUN STATES, NIGERIA
}

\author{
A. B. Onadeko ${ }^{1}$ and O. S. Ogoanah ${ }^{2}$ \\ ${ }^{1}$ Department of Zoology, Faculty of Science, University of Lagos, Akoka, Nigeria \\ ${ }^{2}$ Department of Animal and Environmental Biology, University of Benin, Benin City, Nigeria \\ Corresponding author: onadeko2002@yahoo.com / aonadeko@unilag.edu.ng
}

\begin{abstract}
The effect of road kills of anuran species by vehicular traffic on the Ikorodu-Epe/Ejirin-Ijebu Ode road in Lagos and Ogun States was investigated. The mean traffic density on the road during the survey (between 18:30-20:30hr and 06:00 and 07:00hr) was 127 \pm 45 vehicles/hr, which ranged between 72 and 216 vehicles/hr. A total of 738 anuran road mortalities among eight species were recorded [661 (89.6\%) were identifiable, while 77 (10.4\%) were not]. Ptychadena pumilio had the highest mortality of $67 \pm 27.1$ individuals, while Xenopus muelleri and Aubria subsigillata were the least susceptible to road kills. This respectively represented $2.66 \pm 1.5$ and $2.66 \pm 3$ individuals each. Most mortality (256 individuals) occurred on the section of the road bordered by grassland/tertiary vegetation. However there was no significant difference (at P> $0.05)$ between the anurans killed along the different vegetation structures bordering the road $\left(F_{2,21}=0.415\right)$. About 473 live anurans belonging to five species were observed of which $P$. pu-

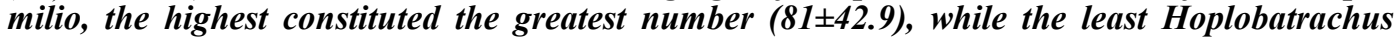
occipitalis $7.3 \pm 4.2$ was recorded. Both species had greater live counts than road kills compared to other anuran species that had greater road kills than live counts recorded. The greatest number of live anurans was recorded at where grassland/tertiary vegetation occurred. This constituted a total of 198 individuals (41.8\%), while the least occurred at the secondary/primary vegetation which had 95 individuals (20\%). However, the difference was not significant $\left(F_{2,12}=0.600\right)$ at $P>0.05$. It is evident that anuran migration is an integral part of their biological activity. However vehicular traffic sadly possesses a negative effect on this activity. Precautionary measures are necessary to reduce population decline and possible extinction of not only the anuran species but also other wildlife species, which is a positive direction in the conservation of biological diversity.
\end{abstract}

Keywords: Vehicular traffic, anuran, mortality, vegetation, road kill, conservation

\section{INTRODUCTION}

Apart from anthropogenic activities such as habitat destruction, industrialization and logging that lead to the reduction of anuran species, road kills have also been another vicious avenue of their demise. Mortality from roadkills may figure among the important causes of decline in amphibian populations and species extinction worldwide (Coelho et al., 2012). According to Mazerolle (2004), there has been 
60

Onadeko et al.

a rise in the development of roads in the various regions of the world in the last half of the $20^{\text {th }}$ century to accommodate the growing needs for quicker transportation and the greater number of cars. This increment has a negative implication, as roads can be deadly especially for small-sized animals such as small mammals, reptiles and amphibians (Adams and Geis, 1983; Fahrig et al., 1995; Ashley and Robison, 1996; Haxton, 2000; Hels and Buchwald, 2001).

The creations of roads also have an adverse effect on amphibian habitation such as habitat loss and fragmentation (Carr and Fahrig, 2001). Fragmentation may lead to isolation of populations which again may result in a reduced population size. This is due to the fact that forest fragments may interrupt migration patterns and increase the accessibility of human incursions leading to a variety of activities that may negatively affect these populations. This might even lead to the risk of extinction of some species (Bennett, 1990). Many major roads stretch over thousands of kilometers or more. These areas on which these roads were created were once habitats to millions of animal species now rendered homeless, dead or may have even led to the extinction of some endemic species.

There are many other effects resulting from the creation of roads, such as the avoidance of roadside area due to modified behavior of organisms (deMaynadier and Hunter, 2000), aquatic and terrestrial communities adjacent to roads are modified due to the exhaust of vehicle or its run off (Turtle, 2000; Trumbulak and Frissell, 2000) and increased predator activity near roads (Boulet and Darveau, 2000).

Direct mortality is the ill-effect resulting from the creation of roads (Clark et al., 1998; Hels \& Buchwald, 2001). Amphibians, due to their activity pattern, population structure and preferred habitats, aquatic breeding species are more vulnerable to traffic mortality than most other animal species. Meek (2012) observed that road-kill had a strong temporal aspect and was associated mostly with migratory movements. This is especially observed during seasonal migration by obligate pond-breeding amphibians that have to cross heavily travelled roads both to and from breeding sites (Holdgate, 1989). Mazerolle et al. (2005) observed both from field surveys and experiments that amphibians tend to remain immobile at the approach of a vehicle, which increases the chance of being killed.

In general, road traffic poses a severe threat to anuran species due to their slow capacity of movement (especially slow moving species), their inability to notice the danger from cars in time and to make successful attempts to avoid them. In Nigeria, many roads stretch over $100 \mathrm{~km}$ or more in tropical regions that are homes to a high diversity of anuran species (Onadeko and Rodel, 2009). Because amphibians have been documented to decline from multiple threats world-wide including transportation infrastructure, which plays a role in this process, this study aimed 1) to detect road mortality of the anuran population along the Ikorodu-Epe/Ejirin-Ijebu Ode roads and 2) to examine whether road kills occurred randomly or at specific spots related to anuran species migratory pathways. The results of this study would aid in understanding the potential environmental impacts of more road creation on anuran populations.

\section{MATERIALS AND METHODS}

\section{Study site and survey area}

The study site is located in two states (Lagos and Ogun) in Nigeria. The area studied was on the Ikorodu-Epe/Ejirin-Ijebu Ode roads connecting the two towns of Epe (in Lagos state) and Ijebu-Ode (in Ogun state). The two lane road (one in each direction) is about $26 \mathrm{~km}$ long and the width between $6-8 \mathrm{~m}$ at different parts along it. Prominent towns located along this road include Irete, Odo-Jabore, Igisile and AlaIjebu. The vegetation along the road is dominated by grassland and tertiary growth occasioned by few secondary/primary forests and swamps (Plate 1).

\section{Quantification of road kills and habitat asso- ciation}

Considering the seasonal variation of anuran activity, the surveys were conducted during the rainy season in the months of June, July and August 2010 and 2011. The survey was carried out mainly during precipitation or after heavy 


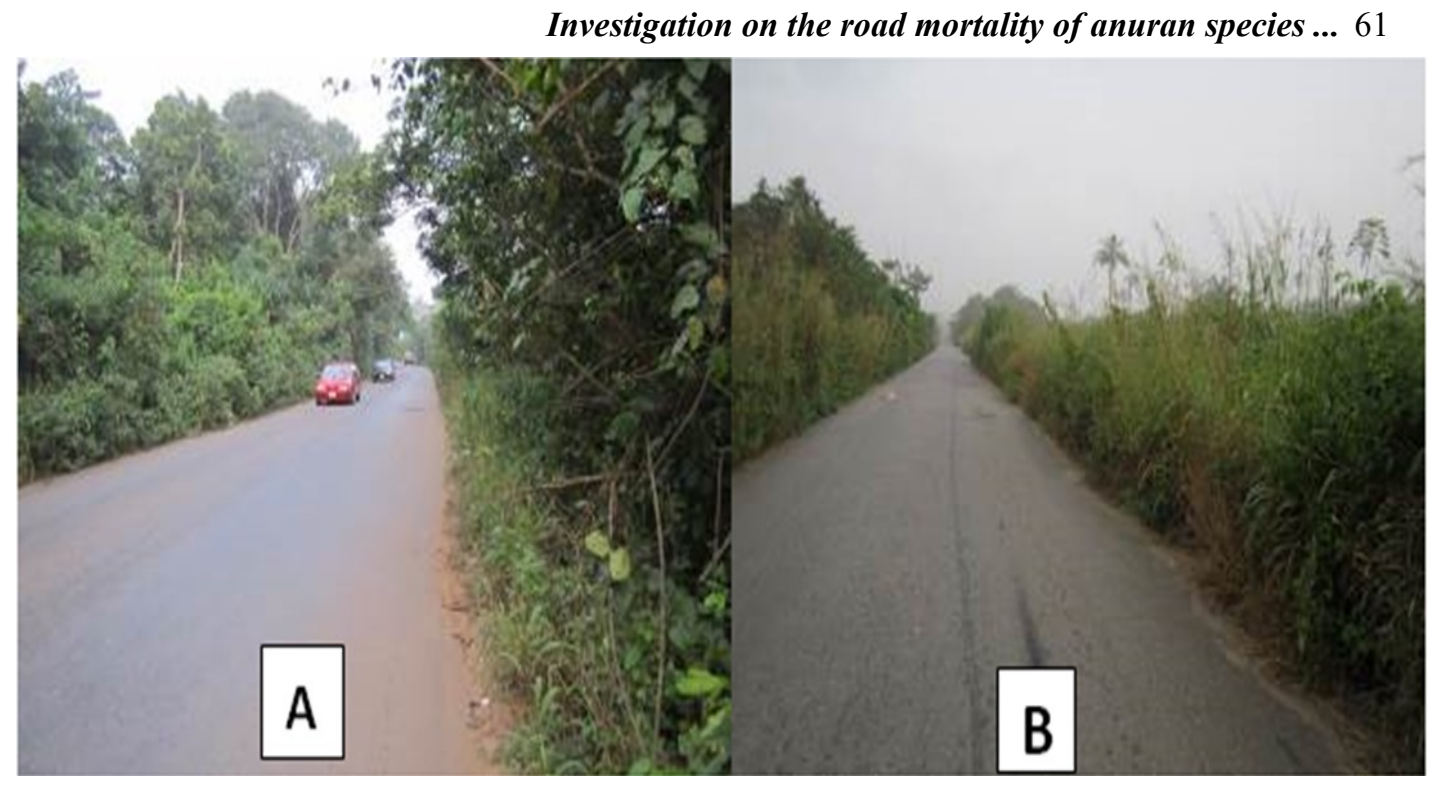

Plate 1: Segments of road bordered by A) Secondary/primary forests and B) Grasses and tertiary vegetation

rains. The road was divided into portions of six segments based on vegetation and landscape types (Table 1). Location of each road segment was recorded at its midpoint with a Garmin Etrex Global Positioning System (GPS) recorder. There were five walks in each segment during the year where all dead anurans were recorded and collected (removed from the road), which allowed for easy counting of new mortality cases. Live specimens crossing during the survey were also recorded and identified. The walk was considered as a form of line transect where the road became the transect (Klauber, 1939). The anurans collected were identified to species level (if identifiable) and recorded as unidentified if such individual could not be categorized into genus or species.

\section{Traffic intensity}

We used vehicle encounter rate to represent traffic volume (Gu et al., 2011). The vehicle encounter rate was calculated by the number of vehicle divided by the survey time. Hourly traffic levels were conducted during the period of survey and analysis applied to mean values (vehicles/h).
Every vehicle (trucks, buses, cars and motorbikes) encountered during the survey was recorded.

\section{Data analysis}

Data on anuran killed and those recorded alive were collated separately to arrive at the total number of road kills and those crossing respectively at the different survey sites according to vegetation structure. The Analysis of Variance (ANOVA) was used to ascertain the significant differences at $\mathrm{P}>0.05$ exist between the numbers killed and the live specimens observed at the different vegetation structures bordering the road respectively.

\section{RESULTS}

During this preliminary survey, a total of 738 anuran road mortalities among eight species were recorded [661 (89.6\%) and were identifiable, while $77(10.4 \%)$ were not] for the years of 2010 and 2011 (Table 2). The mean traffic density on the road during the survey (between 18:30-20:30hr and 06:00 and 07:00hr) was 127 \pm 45 vehicles/hr, ranging between 72 and 216 vehicles/hr. Ptychadena pumilio had the high- 
est mortality recorded which was $67 \pm 27.1$ individuals followed by Amietophrynus regularis $(61.7 \pm 14.5$ individuals), while the species least susceptible to road kills were Xenopus muelleri and Aubria subsigillata which had $2.66 \pm 1.5$ and $2.66 \pm 3$ respectively. Most mortality (256 individuals) occurred on the section of the road where the vegetation was mainly of the tertiary type of vegetation bordering the road.

In Fig. 1, it was observed that the highest road kills in the secondary/primary vegetation $\left(\underline{A}_{\mathrm{VEG}}\right)$ along the road was Amietophrynus regularis (46 individuals), while the least was Xenopus muelleri (1 individual). For the grassland/tertiary vegetation $\left(\mathrm{B}_{\mathrm{VEG}}\right)$, Ptychadena pumilio had the greatest road kills (90 individuals). There were no records of Hoplobatrachus occipitalis and Aubria subsigillata killed in this section of the vegetation bordering the road. A. regularis also had the highest record of road kills in the swampy region with the least being the Xenopus sp. A. regularis had the highest percentages of individuals killed in both $A_{V E G}$ and $C_{V E G}$ vegetation bordering the road, which recorded $28.3 \%$ and $30.9 \%$ respectively (Fig. 2). P. pumilio had the highest mortality in the $\mathrm{B}_{\mathrm{VEG}}$ which was $34.6 \%$. The other anuran species $(H$. occipitalis, A. subsigillata and $X$. muelleri) generally had few percentages of road kills when compared to the others.

A total of 473 anurans belonging to five species were observed crossing the road during the survey (Table 3 ). The number of $P$. pumilio $(81 \pm 42.9$ individuals $)$ was the greatest while the least was $H$. occipitalis (7.3 \pm 4.2 individuals). Both $P$. pumilio and H. occipitalis had greater live counts than road kills (Tables 2 and 3 ) compared to other anuran species that had more road kills than live counts recorded.

The highest crossing of anurans across the road was at $\mathrm{B}_{\mathrm{VEG}}$ vegetation with a total of 198 individuals $(41.8 \%)$, while the least occurred at $A_{\mathrm{VEG}}$ vegetation, which had 95 $(20 \%)$ crossing. Fig. 3 shows that $P$. pumilio highest crossing in all the different 
Investigation on the road mortality of anuran species ...

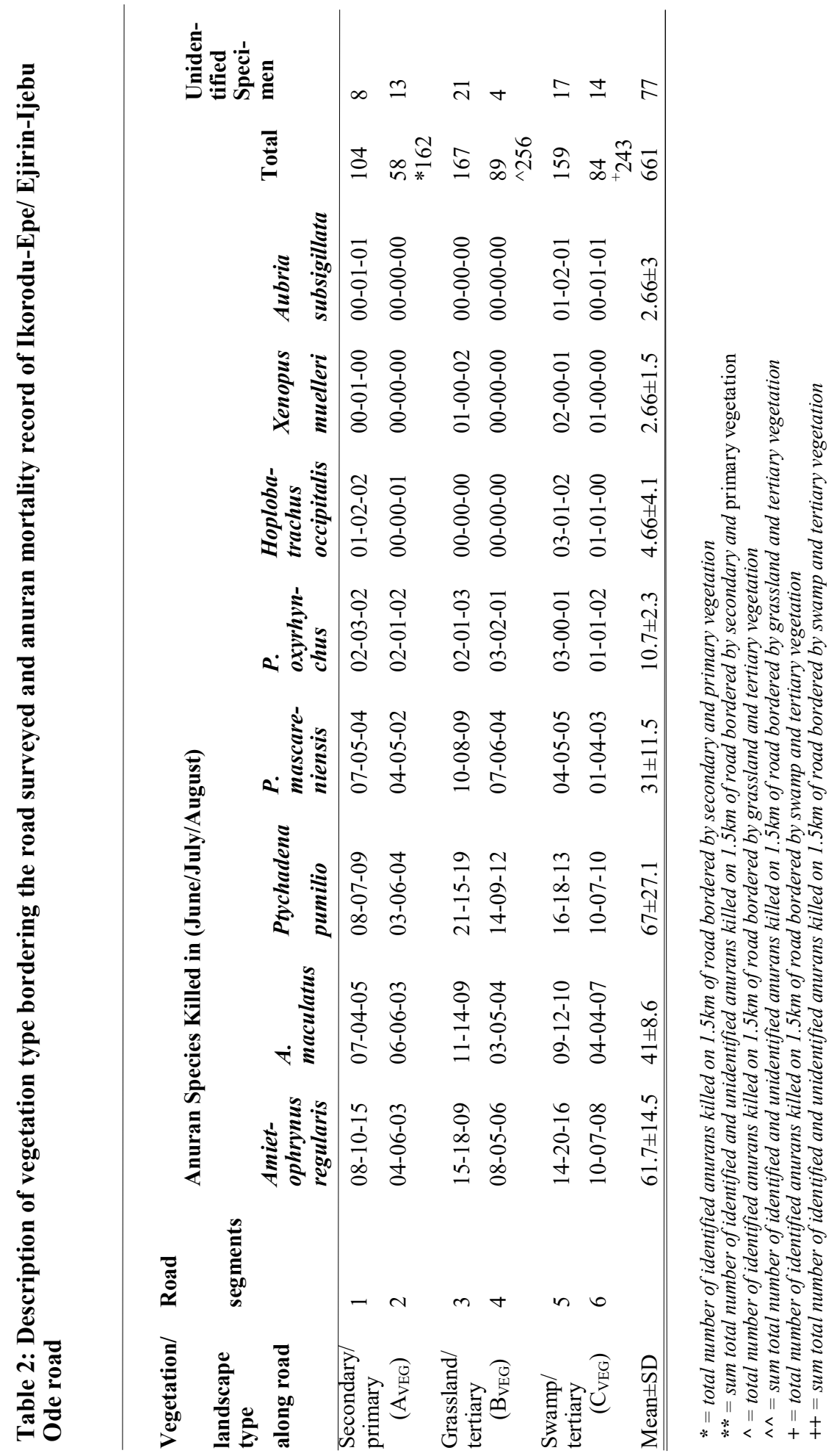

Journal of Science and Technology @ KNUST August 2017 


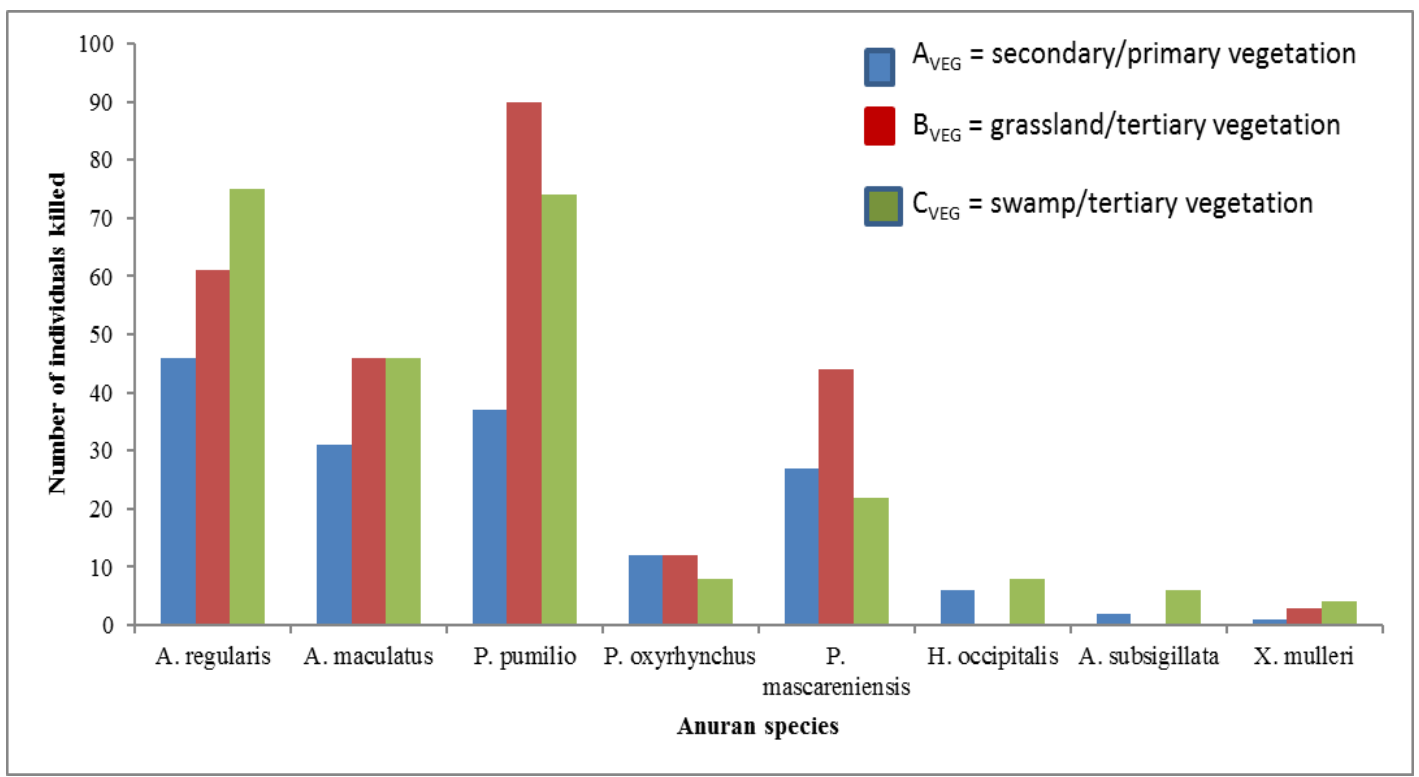

Fig. 1: Number of individual anuran species killed at different vegetation types bordering along Ikorodu-Epe/Ejirin-Ijebu Ode road

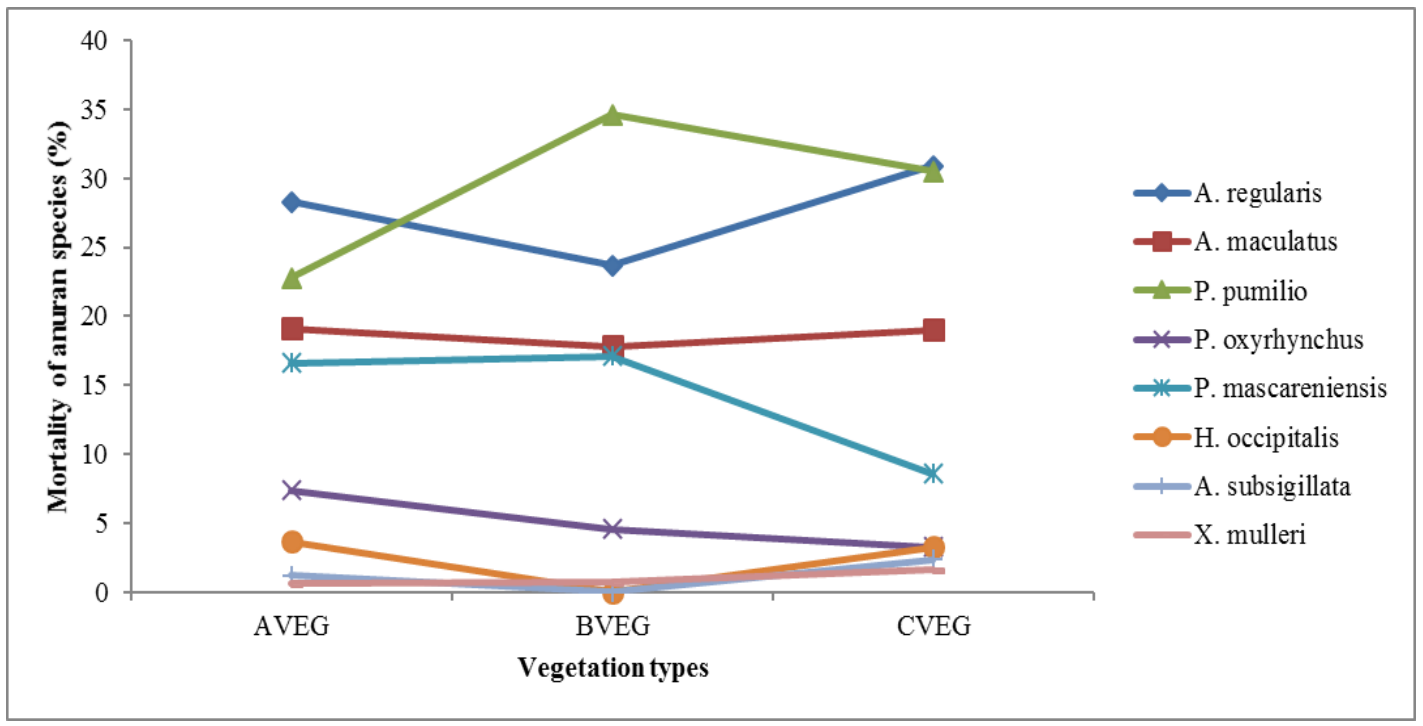

Fig. 2: Percentage mortality of anuran species observed at different vegetation structures bordering along the Ikorodu-Epe/Ejirin-Ijebu Ode road 
Investigation on the road mortality of anuran species ... 65

Table 3: Description of road surveyed and live anuran species recorded along the IkoroduEpe/Ejirin-Ijebu Ode road

\begin{tabular}{|c|c|c|c|c|c|c|c|c|}
\hline \multirow{2}{*}{$\begin{array}{l}\text { Vegetation/ } \\
\text { landscape } \\
\text { type bor- } \\
\text { dering road }\end{array}$} & \multirow{2}{*}{$\begin{array}{l}\text { Road } \\
\text { segments }\end{array}$} & \multicolumn{7}{|c|}{ Anuran Species Crossing in (June/July/August) } \\
\hline & & $\begin{array}{l}\text { Amiet- } \\
\text { ophrynus } \\
\text { regularis }\end{array}$ & $\begin{array}{l}\text { A. macu- } \\
\text { latus }\end{array}$ & $\begin{array}{l}\text { Ptychadena } \\
\text { pumilio }\end{array}$ & $\begin{array}{l}\text { P. mascare- } \\
\text { niensis }\end{array}$ & $\begin{array}{l}\text { Hoploba- } \\
\text { trachus } \\
\text { occipitalis }\end{array}$ & Total & $\begin{array}{l}\text { Sum } \\
\text { Total }\end{array}$ \\
\hline \multirow{3}{*}{$\begin{array}{l}\text { Secondary/ } \\
\text { primary } \\
\left(A_{\mathrm{VEG}}\right)\end{array}$} & \multirow{2}{*}{1} & $04 / 02 / 03$ & $01 / 02 / 06$ & $09 / 12 / 11$ & 03/05/08 & $01 / 03 / 00$ & \multirow{3}{*}{$\begin{array}{l}70 \\
25\end{array}$} & \multirow{3}{*}{95} \\
\hline & & $02 / 03 / 02$ & $02 / 00 / 03$ & $03 / 04 / 03$ & $01 / 00 / 01$ & $01 / 00 / 00$ & & \\
\hline & 2 & & & & & & & \\
\hline \multirow{3}{*}{$\begin{array}{l}\text { Grassland/ } \\
\text { tertiary } \\
\left.\text { (B } \text { B }_{\text {VEG }}\right)\end{array}$} & & 07/06/09 & 03/03/02 & $30 / 18 / 21$ & 05/09/04 & $00 / 01 / 00$ & \multirow{3}{*}{$\begin{array}{l}118 \\
80\end{array}$} & \multirow{3}{*}{198} \\
\hline & 3 & $02 / 01 / 01$ & $03 / 02 / 01$ & $21 / 16 / 21$ & 03/03/01 & $01 / 02 / 02$ & & \\
\hline & 4 & & & & & & & \\
\hline \multirow{3}{*}{$\begin{array}{l}\text { Swamp/ } \\
\text { tertiary } \\
\left(\mathrm{C}_{\mathrm{VEG}}\right) \\
\text { Mean } \pm \mathrm{SD}\end{array}$} & 5 & 09/07/10 & 06/04/04 & $16 / 16 / 14$ & 03/08/06 & 02/01/03 & \multirow{3}{*}{$\begin{array}{l}109 \\
71\end{array}$} & \multirow[b]{2}{*}{180} \\
\hline & 6 & $04 / 05 / 03$ & 06/08/07 & $12 / 09 / 07$ & $00 / 02 / 02$ & 02/01/03 & & \\
\hline & & $26.7 \pm 11$ & $21 \pm 12.1$ & $81 \pm 42.9$ & $20.7 \pm 4.5$ & $7.3 \pm 4.2$ & & 473 \\
\hline
\end{tabular}

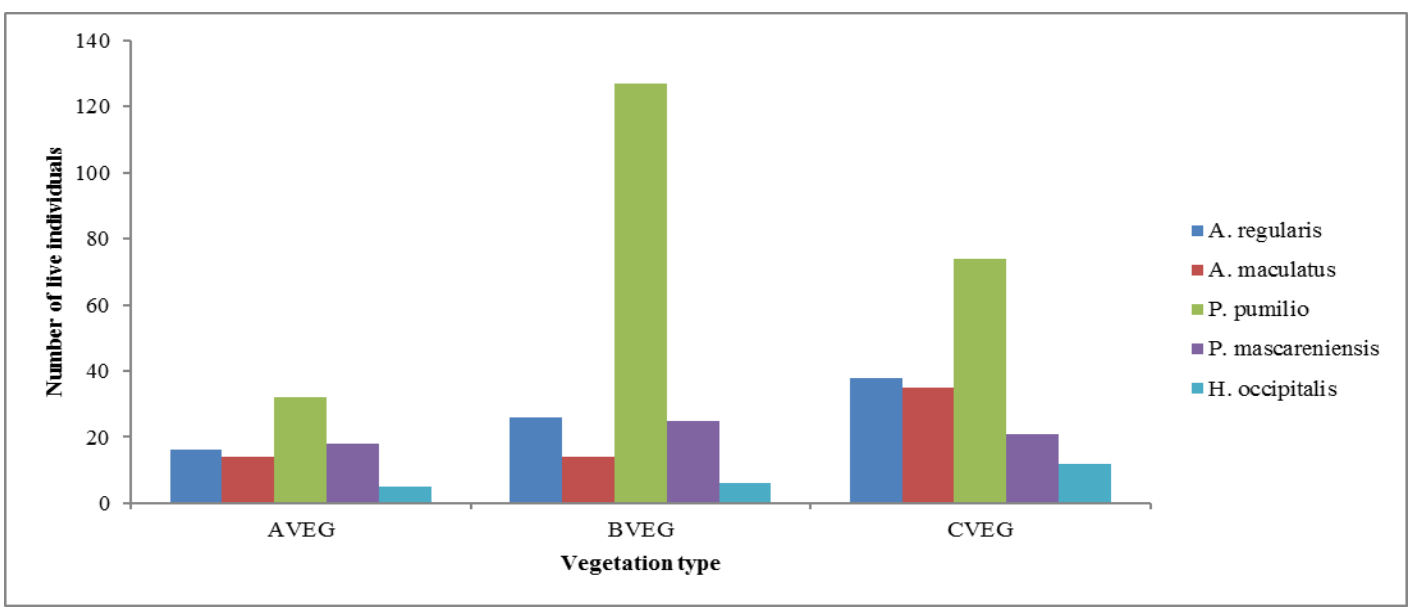

Fig. 3: Number of live anuran species at the different vegetation structures bordering the Ikorodu-Epe/Ejirin-Ijebu Ode road

vegetation structures bordering the road while H. occipitalis was the least.

ANOVA shows that there was no significant difference at $\mathrm{P}>0.05$ between the anurans killed along the different vegetation structures bordering the road $\left(F_{2,21}=0.415\right)$. The greatest num- bers of live anurans were recorded where grassland/tertiary vegetation occurred, which constituted a total of 198 individuals $(41.8 \%)$, while the least occurred at the secondary/ primary vegetation, which had 95 individuals (20\%). However, the differences were not significant $\left(\mathrm{F}_{2,12}=0.600\right)$ at $\mathrm{P}>0.05$. 


\section{DISCUSSION}

Our preliminary data on anuran road-kills revealed that vehicular traffic activity has a huge effect on anuran survival and diversity. Because of increasing human population and the need of adequate transportation, construction of roads are often situated along the edge of geographic features that provide different habitats to anuran species, breeding and foraging sites. In most cases, the road construction divides or cuts habitats into smaller fragments (Dodd et al., 2004) which cause road-kill problems as long as the animals are active (Puky, 2003). These situations represent a true picture of south-western Nigeria, a tropical nation that supports a high diversity of anuran population (Onadeko and Rodel, 2009). However, most surveys are underestimated, as some road-kills are likely to be lost due to scavenging, total obliteration by vehicular impact or some individuals may die off the road where they are not seen.

The spatio-temporal pattern of anuran road-kill is influenced by various factors, one of which is habitat characteristics. From our results, the highest mortalities occurred along the road bordered by grasses and tertiary vegetations despite the absence of two species (H. occipitalis and $A$. subsigillata) in this section of vegetation. This was due to the high occurrence of $P$. pumilio which is the most dominant species in that environment. They inhabit mostly the grasses close to the roadside and during rains (especially at night); they were observed crossing the road frequently. Many of these species were killed as a result of their huge population compared to the other anuran species. Similar observations by Ashley and Robinson (1996) also revealed that Rana pipens road kill was significantly associated with roadside vegetation. According to $\mathrm{Gu}$ et al. (2011), wet grassland is one of the most important habitats for amphibians. They observed that high population density and frequent activity of the amphibian in such areas contribute to the large number of road mortalities.

Water is another important factor associated with anuran movement. The swampy environment bordering the road had the second greatest mortality rate. A. regularis had the highest mortality, followed closely by $P$. pumilio then A. maculatus. This finding agrees with that for Meek (2012) that in Western France most road kills were recorded for the common toad Bufo bufo that constituted $39 \%$ of all mortalities. Most anuran temporal movement pattern is based on the availability of water mostly for breeding purposes or hibernation during the dry season. The moist swampy environment provides avenues for such sought habitats, hence, the high mortalities observed in this section of the road. This phenomenom was demostrated in the studies done by Beshkov and Jameson (1980) on Bombia varigata that amphibian movement was often associated with water.

In this study, it was revealed that secondary/ primary vegetation bordering the road had the lowest mortality rate compared to the other vegetation structures, though there was no significant difference $(\mathrm{P}>0.05)$ among the species' mortality. This shows that the road kills of anuran species are relatively the same along the different vegetation structures owing to the fact that the entire environment is tropical in nature and it harbours a huge diversity and abundance of these species. The secondary/primary vegetation may have a slightly lower mortality results since it is a more stable environment and some anuran species may not necessarily need to migrate to find more suitable environmental conditions. As observed by Meek (2012), habitat type is one of the parameters largely associated with inter-specific differences in road-kills including extent of movement and precipitation.

There was a significant difference $(\mathrm{P}<0.05)$ of live counts among anuran species from the results of the entire survey period. This maybe due to the difference in the relative abundance and activity pattern of the various species. For example, $P$. pumilio was the most abundant in all the vegetation structures which maybe due to their high abundance. $H$. occipitalis was the least abundant and since they are semi-aquatic species, this might limit their activities in the terrestrial environment.

Within the same duration of the survey time, the mortalities and live crossing of different anuran species were recorded. Some species 
great mortalities but low live counts, while some had low mortalities and great live counts (Tables 2 and 3). For example, A. regularis had 182 road kills and 80 individuals crossing the road while $P$. pumilio had 201 road kills and 243 live counts. Out of the total individuals of each species, $A$. regularis and $P$. pumilio had $69.4 \%$ and $45.2 \%$ mortality respectively. The difference in the percentage mortality of these species might be due to their morphological structure and activity. A. regularis are much larger and slower than $P$. pumilio that are smaller in size and faster. Despite the fewer movements of the toads across the road, more might be killed as a result of large body size, which caused slow movement. There were more movements of the frogs but fewer were killed due to their smaller size and faster movement across the road, which reduced the risk of being killed. This finding agrees with most authors who stressed that velocity is an important factor (Rosen and Lowe, 1994; Schlupp and Podloucky, 1994; van Langevelde and Jaarsma, 1997), as most vulnerable species are day-active and slow moving species. Hels and Buchwald (2001) also clearly stated that one of the three most important factors determining species vulnerability to road mortality is the velocity of the species. This reinterates the fact that $P$. pumilio is smaller with a greater velocity than $A$. regularis that is larger, having a slower velocity. Therefore $A$. regularis will have a greater mortality rate than $P$. pumilio, since its velocity rate of crossing the road is slower.

\section{CONCLUSION AND RECOMMENDA- TION}

It is no doubt that this study provides evidence that vehicular traffic posses a negative effect on anuran population within the tropical region. Anurans maybe the vertebrate group with the highest mortality or most impacted worldwide from road kills.

In trying to reduce anuran road mortality, the construction of barriers in conjunction with underpasses or tunnels could separate vehicles from these organisms (Close, 1995; Ryser and Grissenbacher, 1989; Kobylarz, 2001; Puky, 2003), which would allow them to travel between different habitats. The public, especially drivers, could be educated and alerted with anuran crossings through the posting of road signboards in special areas with high diversity and abundance of anuran population. These precautions could go a long way in helping to reduce the population decline and possible extinction of not only some of the anuran species but also other wildlife species, which is a positive direction in the conservation of biological diversity.

\section{REFERENCES}

Adams, L.W. and Geis, A.D. (1983). Effects of roads on small mammals. Journal of Applied Ecology, 20: 403-415.

Ashley, E. P. and Robinson, J. T. (1996). Road mortality of amphibians, reptiles and other wildlife along the point causeway, Lake Erie, Ontario. Canadian Field Naturalist, 110 (3): 403-412.

Bennett, A. F. (1990). Habitat Corridors: Their role in Wildlife Management and Conservation. Department of Conservation and Environment. Melbourne Australia.

Beshkov, V. A. and Jameson. D. L. (1980). Movement and abundance of the yellowbellied toad Bombina variegata. Herpetologica, 36:365-370.

Boulet, M. and Darveau, M. (2000). Depredation of artificial bird nests along roads, rivers and lakes in a boreal balsam fir, Abies balsamea, forest. Canadian Field-Naturalist, 114: $83-88$

Carr, L.W., Fahrig, L. (2001). Effect of road traffic on two amphibian species of differing vagility. Conservation Biology, 15 (4): 10711078.

Clark, G. P., White, P. C. and Harris, S. (1998). Effects of roads on badger Meles meles population in south-west England. Biological Conservation, 86: 117-124.

Close, I. (1995). Conservation Briefs: Frog tunnel. Forest and Bird, 277: 6.

Coelho, I. P., Teixeira, F. Z., Colombo, P., Coelho, P.V.A. and Kindel, A. (2012). Anu- 
ran road-kills neighboring a peri-urban reserve in the Atlantic Forest, Brazil. Journal of Environmental Management, 112: 17-26.

deMaynadier, P.G. and Hunter, M. L. (2000). Road effects on amphibian movements in a forested landscape. Natural Areas Journal, 20: $56-65$.

Dodd, K. C., Barachivich, W. J. and Smith, L. L. (2004). Effectiveness of a barrier wall and culverts in reducing wildlife mortality on a heavily travelled highway in Florida. Biological Conservation, 118: 619-631.

Fahrig, L., Pedlar, J. H., Pope, S. E., Taylor, P. D. and Wager, J. F. (1995). Effect of road traffic on amphibian density. Biological Conservation, 73: 177-182.

Gu, H., Dai, Q., Wang, Q and Wang, Y. (2011). Factors contributing to amphibian road mortality in a wetland. Current Zoology, 57(6): 768-774.

Haxton, T. (2000). Road mortality of snapping turtles, Chelydra serpentina, in central Ontario during their nesting period. Canadian Field -Naturalist, 114: 106-110.

Hels, T. and Buchwald, E. (2001). The effects of road kills on amphibian population. Biological Conservation, 99: 331-340.

Holdgate, M. W. (1989). Preface. Pp.3. In T.E.S.Langton (Ed). Amphibians and Roads. Proceedings of the Toad Tunnel Conference, Rendsburg, Federal Republic of Germany. ACO Polymer Products Ltd., Shefford, U.K.

Klauber, L. M. (1939). Studies of reptile life in the arid southwest. Part 1. Night collecting on the desert with ecological statistics. Bulletin of the Zoological Society of San Diego, 14: 7-64

Kobylarz, B. (2001). The effect of road type and traffic intensity on amphibian road mortality. Journal of Service Learning in Conservation Biology, 1:10-15.

Mazerolle, M. J. (2004). Amphibian road mor- tality in response to nightly variations in traffic intensity. Herpetologica, 60: 45-53.

Mazerolle, M. J., Huot, M. and Gravel, M. (2005). Behaviour of amphibians on the road in response to car traffic. Herpetologica, 61: 380-388.

Meek, R. (2012). Patterns of amphibian roadkills in the Vendée Region of Western France. Herpetological Journal, 22: 51-58.

Onadeko, A.B. and Rodel, M. O. (2009). Anuran surveys of south-western Nigeria. Salamandra, 45: 1-14.

Puky, M. (2003). Amphibian mitigation measures in Central-Europe. In Irwin, L. C., Garrett, P. and McDermott, K. P. (eds): 2003 Proceedings of the International Conference on Ecology and Transportation, The Center for Transportation and the Environment, Raleigh, North Carolina (24-29 August, 2003, Lake Placid, New York). pp. 413-429.

Rosen, P.C. and Lowe, C. H. (1994). Highway mortality of snakes in the Sonoran desert of Southern Arizona. Biological Conservation, 68: 143-148.

Ryser, J. and Grossenbacher, K. (1989). A survey of amphibian preservation at roads in Switzerland. In Langton, T. E. S. (ed): Amphibians and Roads. ACO Polimer Products Ltd., London. 7-13.

Schlupp, I. and Podloucky, R. (1994). Changes in breeding site fidelity - a combined study of conservation and behavior in the common toad Bufo bufo. Biological Conservation, 69: 285-291.

Trombulak, S. C., Frissell, C. A., (2000). Review of ecological effects of roads on terrestrial and aquatic communities. Conservation Biology, 14: 18-30.

Turtle, S. L. (2000). Embryonic survivourship of the spotted salamander A mbystoma maculatum in roadside and woodland vernal pools in Southeastern New Hampshire. Journal of Herpetology, 34: 60-67. 
van Langevelde, F and Jaarsma, C. F. (1997). Habitat fragmentation, the role of minor roads and their travarsality. In: Canters, K. (Ed), Habitat Fragmentation and Infrastructure, Proceedings of the International Confer- ence on Habitat Fragmentation, Infrastructure and the Role of Ecological Engineering, September 1995, The Netherlands. Ministry of Transport, Public Works and Water Management, The Netherlands, pp. 171-182.

\section{APPENDIX I}

Statistical analysis of different vegetation with anurans mortalities

\begin{tabular}{|c|c|c|c|c|c|c|c|c|}
\hline \multicolumn{9}{|c|}{ Descriptives } \\
\hline & & & & & $\begin{array}{l}95 \% \text { Confiden } \\
\text { for Mean }\end{array}$ & ce Interval & & \\
\hline & $\mathbf{N}$ & Mean & Std. Deviation & Std. Error & Lower Bound & Upper Bound & Minimum & Maximum \\
\hline 1 & 8 & 20.2500 & 17.23576 & 6.09376 & 5.8405 & 34.6595 & 1.00 & 46.00 \\
\hline 2 & 8 & 32.0000 & 33.45359 & 11.82763 & 4.0321 & 59.9679 & .00 & 90.00 \\
\hline 3 & 8 & 30.3750 & 30.47218 & 10.77354 & 4.8996 & 55.8504 & 4.00 & 75.00 \\
\hline Total & 24 & 27.5417 & 27.23645 & 5.55962 & 16.0407 & 39.0426 & .00 & 90.00 \\
\hline
\end{tabular}

\section{ANOVA}

\begin{tabular}{lccccc}
\hline Species & & & & & \\
& Sum of Squares & df & Mean Square & F & Sig. \\
\hline Between Groups & 648.583 & 2 & 324.292 & .415 & .666 \\
Within Groups & 16413.375 & 21 & 781.589 & & \\
Total & $\mathbf{1 7 0 6 1 . 9 5 8}$ & $\mathbf{2 3}$ & & & \\
\hline
\end{tabular}

\section{Post Hoc Tests}

\section{Multiple Comparisons}

Dependent Variable: Species

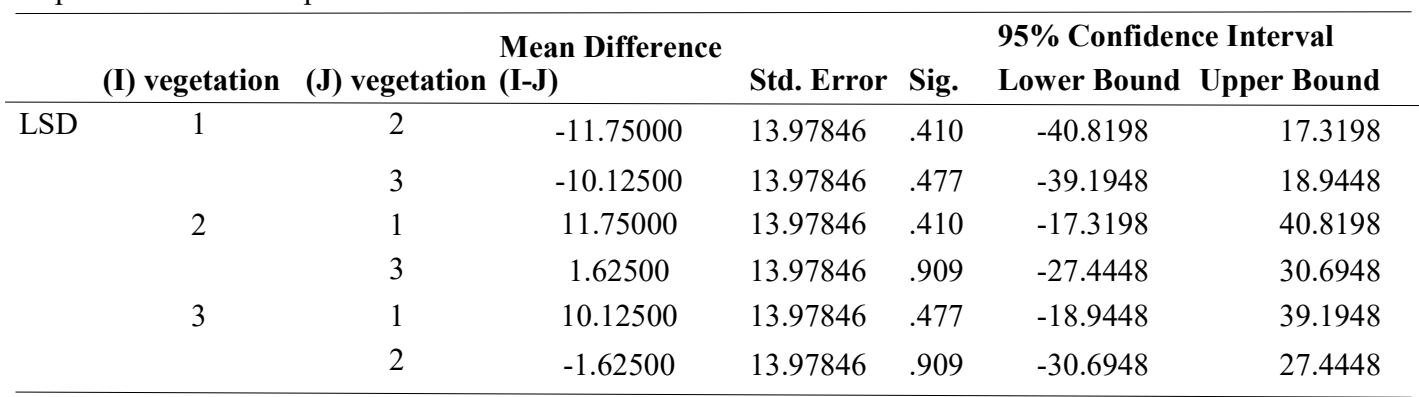




\section{APPENDIX II}

Statistical analysis of different vegetation with live anurans crossing

\section{Descriptives}

Species

95\% Confidence Interval for

Mean

\begin{tabular}{lllllllll} 
& N & Mean & \multicolumn{2}{c}{ Std. Deviation } & Std. Error & Lower Bound & Upper Bound & \multicolumn{2}{c}{ Minimum Maximum } \\
\hline 1 & 5 & 18.4000 & 14.09965 & 6.30555 & .8930 & 35.9070 & 4.00 & 42.00 \\
2 & 5 & 39.6000 & 49.55098 & 22.15987 & -21.9257 & 101.1257 & 6.00 & 127.00 \\
3 & 5 & 36.0000 & 23.71708 & 10.60660 & 6.5514 & 65.4486 & 12.00 & 74.00 \\
Total & $\mathbf{1 5}$ & $\mathbf{3 1 . 3 3 3 3}$ & $\mathbf{3 1 . 7 9 5 4 8}$ & $\mathbf{8 . 2 0 9 5 6}$ & $\mathbf{1 3 . 7 2 5 6}$ & $\mathbf{4 8 . 9 4 1 1}$ & $\mathbf{4 . 0 0}$ & $\mathbf{1 2 7 . 0 0}$
\end{tabular}

ANOVA

\begin{tabular}{llllll}
\hline species & Sum of Squares & Df & Mean Square & F & Sig. \\
\hline Between Groups & 1286.933 & 2 & 643.467 & .600 & .564 \\
Within Groups & 12866.400 & 12 & 1072.200 & & \\
Total & $\mathbf{1 4 1 5 3 . 3 3 3}$ & $\mathbf{1 4}$ & & & \\
\hline
\end{tabular}

\section{Post Hoc Tests}

Multiple Comparisons

Dependent Variable: Species

\begin{tabular}{|c|c|c|c|c|c|c|c|}
\hline & \multirow{2}{*}{$\begin{array}{l}\text { (I) vege- } \\
\text { tation }\end{array}$} & \multirow{2}{*}{$\begin{array}{l}(\mathrm{J}) \text { vegeta- } \\
\text { tion }\end{array}$} & \multirow[b]{2}{*}{ Mean Difference (I-J) } & \multirow[b]{2}{*}{ Std. Error } & \multirow[b]{2}{*}{ Sig. } & \multicolumn{2}{|c|}{ 95\% Confidence Interval } \\
\hline & & & & & & Lower Bound & Upper Bound \\
\hline \multirow[t]{6}{*}{ LSD } & \multirow[t]{2}{*}{1} & 2 & -21.20000 & 20.70942 & .326 & -66.3219 & 23.9219 \\
\hline & & 3 & -17.60000 & 20.70942 & .412 & -62.7219 & 27.5219 \\
\hline & \multirow[t]{2}{*}{2} & 1 & 21.20000 & 20.70942 & .326 & -23.9219 & 66.3219 \\
\hline & & 3 & 3.60000 & 20.70942 & .865 & -41.5219 & 48.7219 \\
\hline & \multirow[t]{2}{*}{3} & 1 & 17.60000 & 20.70942 & .412 & -27.5219 & 62.7219 \\
\hline & & 2 & -3.60000 & 20.70942 & .865 & -48.7219 & 41.5219 \\
\hline
\end{tabular}

